\title{
Implementasi Pendidikan Madrasah Diniyah dalam Penguatan Mata Pelajaran PAI di SMP Negeri Mamba'ul Falah Kedungliwung Kemiri Singojuruh Kabupaten Banyuwangi
}

\author{
Ahmad Hasyim Fauzan, \\ Fakultas Tarbiyah, IAI Ibrahimy Genteng Banyuwangi \\ e-mail: fauzan@iaiibrahimy.ac.id
}

\begin{abstract}
This study aims to describe the implementation of Early Islamic Education in Middle School Manba'ul Falah Kedungliwung Kemiri Singojuruh Banyuwangi. This research is a descriptive study with a qualitative approach. The techniques carried out in the analysis of the data are display data, data reduction, and conclusion. The validity of the data is done through continuous observation, technical triangulation, and member check. The results showed that structure of Diniyah Madrasa Manba'ul Falah State Middle School contains objective religious education values. MADIN implementation in the classroom is developed through spontaneous activities, routine activities and conditioning. MADIN's educational values developed are students becoming people who are fasanah wafilakhiroti hasanah (good people in the world and good people in the hereafter).
\end{abstract}

Keywords: implementation of madrasah diniyah, reinforcement of islamic education subjects

\begin{tabular}{|c|c|c|}
\hline Accepted: & Reviewed: & Publised: \\
Desember 22 2018 & Januari 13 2019 & Februari 28 2019 \\
\hline
\end{tabular}

\section{PENDAHULUAN}

Seiring dengan tantangan zaman, pendidikan merupakan hal yang sangat penting, terlebih pendidikan agama karena pendidikan salah satu penentu mutu sumber daya manusia. Pendidikan agama merupakan pondasi dari berbagai macam disiplin ilmu sehingga agama merupakan penentu arah. Agama sebagai pengontrol dan lain sebagainya. Setiap sekolah berusaha dan berupaya bagaimana caranya untuk memperdalam agama yang efektif. Dewasa ini, keunggulan suatu bangsa tidak lagi ditandai dengan melimpahnya kekayaan alam, melainkan pada keunggulan Sumber Daya Manusia (SDM). Di mana mutu Sumber Daya Manusia (SDM) berkorelasi positif dengan mutu pendidikan khususnya pengetahuan atau pemahaman tentang agama, Surat At-Taubah Ayat 122 menerangkan:

This work is licensed under Creative Commons Attribution Non Commercial 4.0 International License Available iaiibrahimy.ac.id 


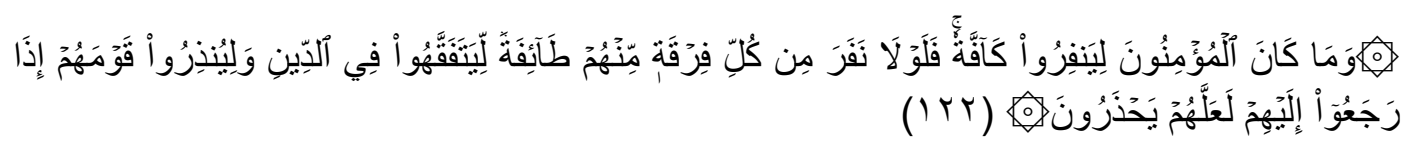

Artinya: Tidak sepatutnya bagi mukminin itu pergi semuanya (ke medan perang). Mengapa tidak pergi dari tiap-tiap golongan di antara mereka beberapa orang untuk memperdalam pengetahuan mereka tentang agama dan untuk memberi peringatan kepada kaumnya apabila mereka telah kembali kepadanya, supaya mereka itu dapat menjaga dirinya (Depag RI, 2002:164).

Mutu pendidikan sering diindikasikan dengan kondisi yang baik, memenuhi syarat, dan segala komponen yang harus terdapat dalam pendidikan, komponenkomponen tersebut adalah masukan, proses, keluaran, tenaga kependidikan, sarana dan prasarana serta biaya. Mutu pendidikan tercapai apabila masukan, proses, keluaran, guru, sarana dan prasarana serta biaya, apabila seluruh komponen tersebut memenuhi syarat tertentu. Namun dari beberapa komponen tersebut yang lebih banyak berperan adalah tenaga kependidikan yang bermutu yaitu yang mampu menjawab tantangan-tantangan dengan cepat dan tanggung jawab. Tenaga kependidikan pada masa mendatang akan semakin kompleks, sehingga menuntut tenaga kependidikan untuk senantiasa melakukan berbagai peningkatan dan penyesuaian penguasaan kompetesinya.

Undang-undang No. 20 Tahun 2003 tentang Sistem Pendidikan Nasional mendefinisikan pendidikan sebagai.

Usaha sadar dan terencana untuk mewujudkan suasana belajar dan proses pembelajaran agar peserta didik secara aktif mengembangkan potensi dirinya untuk memiliki kekuatan spiritual keagamaan, pengendalian diri, kepribadian, kecerdasan, akhlak mulia, serta ketrampilan yang diperlukan dirinya, masyarakat, bangsa dan Negara (UU. Sisdiknas No 20 Thn 2003).

Hal ini berarti bahwa pendidikan merupakan suatu proses atau upaya sadar untuk menjadikan manusia ke arah yang lebih baik. Salah satu pelaksanaan selalu ingin menghasilkan lulusan-lulusan ataupun output yang baik, berkualitas, memiliki prestasi belajar yang bagus dan bisa diandalkan. Untuk mencapai keberhasilan pendidikan tersebut harus melalui beberapa proses dan sistem yang baik.

Madrasah diniyah merupakan program wajib, yang di laksanakan SMP Negeri Manba'ul Falah dalam naungan Pondok Pesantren Manba'ul Falah yang harus diikuti semua siswa-siswi SMP Negeri Manba'ul Falah yang menimba ilmu di 
sana. Sekolah diniyyah merupakan program sekolah yang bertujuan tidak lain demi menghasilkann lulusan-lulusan yang berprestasi khususnya dalam ilmu agama. Untuk mewujudkan semua itu tentunya memakan waktu dan proses sehingga tujuan pendidikan tersebut dapat terealisasi. Maka dalam penelitian ini dipilih SMP Negeri Manba'ul Falah yang menerapkan pendidikan diniyah. Mengingat SMP Negeri Manba'ul Falah tersebut merupakan SMP yang identik dengan pelajaraan keagamaan yang kental.

SMP Negeri Manba'ul Falah menjadi sorotan masyarakat tentang mutu pendidikannya. SMP ini merupakan sebuah lembaga yang dipimpin oleh seorang kepala sekolah yang berusaha menjadikan siswa-siswinya seseorang yang nantinya jadi apapun dia akan menjadi seorang yang muttaqin. Oleh sebab itu, siswa-siswinya diwajibkan mengikuti Sekolah diniyyah untuk menambah pemahamannya tentang mata pelajaran PAI. Kepala sekolah dan dewan guru menyadari atas keterbatasan ruang dan waktu, untuk menyiasati hal tersebut maka kepala sekolah bekerjasama dengan kepala Madin PP Manba'ul Falah untuk merealisasikan pendidikan Madin tersebut. Agar siswa- siswi SMP Negeri Manba'ul Falah dapat menambah pemahaman pada mata pelajaran Pendidikan Agama Islam sesuai dengan apa yang diharapkan oleh semua pihak. Jadi, sekolah yang bermutu dapat dilihat dari prestasi yang sudah diraih, oleh karenanya semua komponen mulai dari kepala sekolah dan para dewan guru serta wali murid sangat berperan sekali terhadap pencapaian tujuan tersebut.

\section{METODE PENELITIAN}

Penelitian ini termasuk jenis penelitian kualitatif. Menurut Sugiyono (2015:297) objek penelitian dalam penelitian kualitatif adalah situasi sosial yang terdiri dari tiga elemen yaitu: tempat, pelaku, dan aktivitas yang berinteraksi secara sinergis. Arah penelitian ini untuk mengetahui bagaimana penerapan program sekolah diniyyah di SMP Negeri Manba'ul Falah Kemiri Singojuruh. Desain penelitian ini menggunakan fenomenologi. Data primer yang digunakan dalam penenlitian yang dilakukan adalah hasil wawancara dengan Kepala Sekolah, Guru PAI dan siswa-siswi SMP Negeri Manba'ul Falah. Sedangkan data sukender yang akan digunakan adalah dokumen (foto dan rekaman) dan penelitian terdahulu yang mendukung.

Menurut Arikunto (2013:183) sampel bertujuan dilakukan dengan cara mengambil subjek bukan didasarkan strata, random atau daerah tetapi di dasarkan adanya tujuan tertentu. Adapun yang menjadi subjek penelitian atau sumber data kualitatif yang digunakan adalah wawancara dengan Kepala Sekolah, Guru PAI dan siswa-siswi kelas IX SMP Negeri Manba'ul Falah. Untuk mengetahui 
bagaimana penerapan program pendidikan diniyah yang di laksanakan maka dalam melakukan pengumpulan data dalam penelitian ini menggunakan wawancara mendalam, observasi dan dokumentasi. Keabsahan data diperoleh melalui triangulasi data dan metode. Teknik analisis data diperoleh melalui reduksi data, penyajian data dan menarik kesimpulan.

\section{HASIL ANALISIS DAN PEMBAHASAN}

Hasil penelitian dan pembahasan dalam Implementasi Pendidikan Madrasah Diniyah dalam Penguatan Mata Pelajaran PAI Kelas IX di SMP Negeri Mamba'ul Falah Kedungliwung Kemiri Singojuruh Banyuwangi dapat diuraikan sebagai berikut.

\section{Pelaksanaan Madrasah Diniyah SMP Negeri Manba'ul Falah}

Program Madrasah Diniyah ini mempunyai 3 tujuan utama yaitu memperbaiki moral siswa, mengembangkan kurikulum PAI yang sesuai dengan kebutuhan para siswa dan memberikan bekal pengetahuan Agama Islam yang lebih banyak untuk seluruh peserta didik. Tujuan diadakanya program madrasah diniyah adalah untuk memberikan pengetahuan agama yang lebih banyak kepada para siswa. Karena jumlah jam pelajaran PAI di kelas terlalu sedikit, maka kurikulum PAI dikembangkan lagi dengan menambah materi-materi keagamaan yang lebih kompleks dan dibutuhkan oleh siswa dalam kehidupan di masyarakat. Setelah itu, jam pelajaran PAI ditambah dalam ekstra kurikuler keagamaan yaitu madrasah diniyah. Selain itu, tujuan program madrasah diniyah juga untuk menanamkan akhlak dan karakter yang baik kepada para siswa di sekolah.

Ada 4 materi yang diajarkan di Madrasah Diniyah SMP Negeri Manba'ul Falah yaitu: Baca Tulis Qur'an (BTQ), Fiqih, Taukhid, dan Akhlaq. Masing-masing materi di atas merupakan materi pokok yang ada di pelajaran PAI Kurikulum K13, kemudian dikembangkan lagi materinya menjadi sub-sub bab baru. Materi-materi yang diajarkan di madrasah diniyah merupakan materi pelengkap yang lebih kompleks dibandingkan dengan materi yang ada dalam buku pelajaran PAI. Materi apa yang tidak ada dalam pelajaran PAI dan itu dirasa perlu diajarkan kepada siswa, maka dicarikan materi dari buku-buku maupun kitab-kitab yang sesuai dengan pelajaran tersebut. Berikut adalah materi-materi dan kitab-kitab yang digunakan sebagai acuan dalam pembelajaran di Madrasah Diniyah: 
Tabel 1. Materi-Materi yang Diajarkan di Madrasah Diniyah SMP Negeri Manba'ul Falah Kemiri Singojuruh

\begin{tabular}{|l|l|l|l|}
\hline No & \multicolumn{1}{|c|}{ Pelajaran } & \multicolumn{1}{|c|}{ Kitab } & \multicolumn{1}{|c|}{ Kelas } \\
\hline 1 & $\begin{array}{l}\text { Baca Tulis } \\
\text { Qur'an } \\
\text { (BTQ) }\end{array}$ & Al-Qur'an, Hidayatul Mustafid & VII, VIII, IX \\
\hline 2 & Fiqih & $\begin{array}{l}\text { Mabadiul Fiqhiyah, } \\
\text { Fasholatan }\end{array}$ & VII, VIII \\
\hline \multirow{2}{*}{4} & Taukhid & Risalatul Mahid & IX \\
\hline 5 & Akhlak & Alala & VII, VIII, IX \\
\cline { 3 - 4 } & & Akhlakul Banin & VII \\
\cline { 2 - 4 } & & Ta'limul Muta'alim & VIII \\
\hline
\end{tabular}

\section{Sumber: Dokumen SMP Negeri Manbaul Falah}

Para pendidik di Madrasah Diniyah SMP Negeri Manba'ul Falah juga memiliki strategi pembelajaran yang beragam sesuai dengan kemampuan mereka, keadaan siswa serta agar kegiatan belajar mengajar di dalam kelas menjadi tertib dan kondusif. Pelajaran Tauhid yang diampu oleh Ustadz Ahmad Nadhirin menggunakan strategi pembelajaran Ekspositori dengan metode Ceramah. Pelajaran BTQ yang diampu oleh Ustadz marzuqi menggunakan strategi pembelajaran Ekspositori dengan metode Demonstrasi. Pelajaran Fiqih yang diampu oleh Ustadz $\mathrm{H}$. Abdurrohman menggunakan strategi pembelajaran Inquiri dengan metode Eksperimen dan Diskusi. Pelajaran Akhlak yang diampu oleh Ustadz Marzuki menggunakan strategi pembelajaran Inquiri Sosial dengan metode Resitasi.

Dari hasil wawancara peneliti dengan keempat orang tersebut dapat diketahui bahwa masing-masing orang menggunakan strategi dan metode pembelajaran yang berbeda-beda sesuai dengan kemampuan guru yang bersangkutan dan juga kondisi di kelas ketika mereka mengajar. Walaupun strategi dan metode pembelajaran berbeda, namun tujuannya tetap sama yaitu agar proses kegiatan belajar mengajar menjadi lebih berkualitas. Para siswa bisa dengan mudah menyerap apa yang disampaikan oleh guru tanpa ada rasa jenuh dan bosan. Pengembangan kurikulum yang dilakukan di SMP Negeri Manba'ul Falah melalui kegiatan madrasah diniyah ini dapat berhasil dan berguna untuk kepentingan sekolah di masa mendatang. 
Evaluasi pendidikan agama ialah suatu kegiatan untuk menentukan taraf kemajuan suatu pekerjaan di dalam pendidikan agama. Evaluasi adalah alat untuk mengukur sampai di mana penguasaan murid terhadap pendidikan yang telah diberikan. Ada dua evaluasi pembelajaran yang dilakukan di madrasah diniyah. Pertama evaluasi formatif (evaluasi jangka pendek) atau dalam prakteknya di sekolah disebut ulangan harian. Di sini para guru menyelesaikan satu pokok bahasan kemudian mengadakan ulangan harian baik dengan ujian tulis maupun ujian praktek tergantung pada mata pelajaran dan sub materinya. Setelah ulangan harian selesei, selanjutnya masing-masing guru menyetorkan nilai hasil ulangan harian kepada Waka Kurikulum yaitu Bapak Imron Masyhadi S.Sos.I.

Yang kedua adalah evaluasi sumative (evaluasi jangka panjang) atau dalam prakteknya di sekolah disebut ulangan akhir semester. Di sini para guru harus menyelesaikan materi yang harus disampaikan kepada siswa selama satu semester. Setelah semua beban materi selesai diadakan ujian akhir semester khusus madrasah diniyah. Soal-soal yang diujikan dibuat oleh para guru yang mengajar di madrasah diniyah. Setelah ujian akhir semester selesai dilakukan, para guru harus menyetorkan seluruh nilai yang diperoleh selama kegiatan belajar mengajar (KBM) di madrasah diniyah baik nilai tugas, ulangan harian, ujian praktek, maupun ujian akhir semester kepada Waka Kurikulum. Nilai-nilai tersebut akan diproses dan dimasukkan ke rapor khusus mata pelajaran madrasah diniyah. Selain ujian tulis, di Madrasah Diniyah SMP Negeri Manba'ul Falah juga mengadakan ujian praktek dan ujian lisan.

Selain evaluasi dalam bentuk ujian, penelitian ini juga menggali data-data tentang evaluasi dalam bentuk hasil yang didapat setelah proses belajar mengajar madrasah diniyah diberlakukan di SMP Negeri Manba'ul Falah Kemiri Kecamatan Singojuruh kabupaten Banyuwangi. Setelah menjalankan program keagamaan madrasah diniyah, tentunya terdapat perubahan yang dirasakan baik oleh kepala sekolah, dewan guru maupun peserta didik. Hasil yang didapat dan dirasakan ini merupakan tolak ukur tingkat keberhasilan dalam kegiatan pembelajaran di madrasah diniyah. Peneliti berusaha melakukan wawancara dengan kepala sekolah dan beberapa peserta didik yang belajar dikelas.

Pertama dilakukan wawancara dengan kepala sekolah mengenai perubahan yang beliau rasakan setelah kegiatan madrasah diniyah dilaksanakan. Dalam hal ini beliau menjelaskan:

Alhamdulillah pak banyak sekali perubahan pada anak-anak yang saya rasakan setelah kegiatan madrasah diniyah ini berjalan terutama dalam hal akhlak dan ibadah. Sekarang saya jarang sekali mendengar anak-anak berkata kotor (misuh) seperti dulu mereka sudah mulai 
membiasakan diri bersikap sopan kepada guru. Dan yang paling membuat saya bahagia adalah sekarang anak-anak sudah rutin melaksanakan sholat berjamaah baik di rumah terutama di sekolah. Dulu banyak wali murid yang mengeluh anak-anaknya tidak pernah melakukan sholat wajib 5 waktu di rumah. Tapi dengan kegiatan madrasah diniyah ini perlahan tapi pasti anak-anak sudah rutin melaksanakan sholat di rumah. Saya pernah mendengar ada salah satu anak yang berkata kalau satu hari saja tidak melaksanakan sholat dhuha maka rasanya seperti ada yang kurang. Ini adalah bukti bahwa mereka sudah memiliki kesadaran dalam beribadah. Ada juga anak-anak yang mengikuti kegiatan diba' di rumah mereka kemudian diberikan materi yang sama dengan materi yang mereka dapatkan di madrasah diniyah. Ini sangat bermanfaat bagi perkembangan sekolah kedepanya terutama ketika penerimaan siswa baru (PPDB). Dengan adanya kegiatan madrasah diniyah ini maka animo masyarakat terhadap SMP Negeri Mamba'ul falah semakin meningkat.

Melihat penjelasan kepala sekolah di atas, dapat disimpulkan bahwa ada perubahan besar pada diri peserta didik setelah mengikuti kegiatan keagamaan madrasah diniyah. Kemudian peneliti mencoba mengadakan wawancara dengan beberapa orang peserta didik SMP Negeri Manba'ul Falah. Selanjutnya penelitian ini akan menggali sejauh mana perubahan yang mereka alami setelah aktif belajar di madrasah diniyah. Oleh sebab itu dilakukan wawancara dengan siswi kelas IX yaitu Hilmi Amirul Mustofa. Terdapat beberapa pertanyaan mengenai perubahan yang dialami setelah mengikuti kegiatan madrasah diniyah. Dalam wawancara tersebut Amirul Hilmi menjelaskan:

Banyak perubahan yang saya alami setelah mengikuti pembelajaran agama di madrasah diniyah pak terutama dalam hal wawasan keilmuan agama Islam. Sejak sekolah mengadakan madrasah diniyah, saya mendapatkan materi agama yang beragam seperti anal-anak yang nyantri di pondok. Di madrasah diniyah juga memakai kitab kuning seperti di pondok. Sekarang saya dapat memahami ilmu-ilmu agama yang lebih banyak dari biasanya. Perubahan juga saya alami dalam hal ibadah. Sebelumnya saya jarang sholat berjamaah di rumah, tetapi sekarang saya rutin sholat berjamaah walaupun tidak di musholla atau masjid. Selain itu saya juga rutin membaca al-Qur'an di rumah

Melihat penjelasan di atas, peneliti dapat mengambil kesimpulan bahwa kegiatan madrasah diniyah di SMP Negeri Manba'ul Falah berdampak sangat 
positif bagi siswa terutama dalam hal ibadah sehari-hari dan juga menambah wawasan keilmuan agama mereka.

\section{SIMPULAN}

Dari beberapa uraian yang telah dikemukakan sebelumnya dapat diambil kesimpulan mengenai Implementasi Madrasah Diniyah pada Mata Pelajaran PAI di SMP Negeri Manba'ul Falah Kemiri Singojuruh dijabarkan menjadi sub-sub bab sebagai berikut.

1. Tujuan Program Keagamaan Madrasah Diniyah SMP Negeri Manba'ul Falah Kemiri Singojuruh

Ada tiga tujuan pokok diadakanya program keagamaan Madrasah Diniyah yaitu pertama, sebagai sarana untuk mengembangkan kurikulum PAI di sekolah. Mata pelajaran PAI yang hanya 2 jam pelajaran satu minggu dirasa sangat kurang serta untuk membekali siswa dengan pengetahuan agama yang cukup. Maka solusinya adalah dengan menambah jam pelajaran PAI dalam ekstrakurikuler yang wajib diikuti oleh seluruh siswa. Kedua, untuk mengatasi degradasi moral yang terjadi kepada siswa yang belajar di sekolah. Kurangnya pengetahuan agama membuat para siswa melakukan berbagai pelanggaran baik pelanggaran hukum maupun pelanggaran dalam ranah agama. Salah satu cara yang dapat dilakukan untuk menanggulangi masalah tersebut adalah dengan memberikan pengetahuan Agama Islam kepada para peserta didik disekolah. Pendidikan Agama Islam di sekolah, terutama sekolah umum terjadi kekurangan jam pelajaran Agama Islam. Hal inilah yang dianggap menjadi penyebab kurangnya pemahaman agama di kalangan siswa. Sebagai akibatnya, maka banyak siswa yang tidak dapat membentengi dirinya dengan pengaruh negatif yang menghampiri mereka. Serta untuk memberikan wawasan Agama Islam yang lebih luas kepada para siswa yang belajar di sekolah.

2. Materi Yang Diajarkan di Madrasah Diniyah SMP Negeri Manba'ul Falah Kemiri Singojuruh

Ada 4 materi yang berasal dari kitab-kitab klasik sebagai bahan penunjang untuk mengembangkan kurikulum PAI sesuai dengan kebutuhan peserta didik. Keempat materi tersebut adalah: Baca Tulis Qur'an (BTQ) menggunakan Al-Qur'an dan kitab Hidayatul Mustafid. Materi Fiqih menggunakan kitab Mabadiul Fiqhiyah dan Fiqih Wanita. Materi Tauhid menggunakan kitab Akidatul Awam dan Khoridatul 
Bahiyah, dan Materi Akhlak menggunakan kitab Akhlakul Banin danTa'lim Muta'alim.

3. Strategi Pembelajaran di Madrasah Diniyah SMP Negeri Manba'ul Falah Kemiri Singojuruh

Masing-masing guru yang mengajar di Madrasah Diniyah SMP Negeri Manba'ul Falah Kemiri Singojuruh menerapkan strategi dan metode pembelajaran yang berbeda-beda sesuai dengan kemampuan masing-masing guru dan keadaan dikelas ketika guru tersebut mengajar.

4. Evaluasi Pembelajaran di Madrasah Diniyah SMP

Ada dua evaluasi pembelajaran yang dilakukan di Madrasah Diniyah SMP Negeri Manba'ul Falah Kemiri Singojuruh Pertama, evaluasi formatif (evaluasi jangka pendek) atau yang biasa disebut ulangan harian. Kedua, evaluasi sumatif (evaluasi jangka panjang). Selain evaluasi berupa ujian tulis juga ada ujian lisan serta ujian praktek.

5. Implementasi Pengembangan Kurikulum Negeri Manba'ul Falah Kemiri Singojuruh

a. Perencanaan Pengembangan Kurikulum PAI

Para guru di SMP Negeri Manba'ul Falah Kemiri Singojuruh sudah sering mengikuti pelatihan tingkat kabupaten seperti UKG, KKG, MGMP dan lain sebagainya. Jadi mereka sudah mengerti bagaimana merencanakan pengembangan kurikulum ini terutama dalam pembuatan perangkat pembelajaran seperti RPP, Silabus, Prota, Promes dan lain-lain.

b. Pelaksanaan Pengembangan Kurikulum PAI

Terdapat beberapa hal yang termasuk dalam perencanaan ini yaitu: (1) rombongan belajar yang terdiri dari 6 kelas mulai kelas VII sampai kelas IX. (2) Beban kerja guru yaitu 12 jam pelajaran setiap minggu dengan rincian 2 jam pelajaran masing-masing kelas. (3) Teks Pembelajaran yang memakai modul berupa buku paket PAI dipandu dengan kitab-kitab serta buku-buku lain yang memadai. (4) Pengelolaan kelas yang dilaksanakan oleh setiap guru yang mengajar dengan tujuan agar pembelajaran menjadi aktif dan menyenangkan.

c. Evaluasi Pengembangan Kurikulum PAI

Untuk mengetahui tingkat keberhasilan kegiatan yang dilakukan, maka sekolah mengadakan evaluasi yang di pimpin langsung oleh kepala sekolah. Evaluasi ini bertujuan untuk mengetahui sejauh mana kegiatan madrasah diniyah ini dapat 
merubah pola fikir anak-anak agar lebih giat dalam beribadah dan juga menambah pengetahuan Agama Islam di sekolah.

DAFTAR RUJUKAN :

Arikunto, S. (1998). Prosedur Penelitian: Suatu Pendekatan Praktek. Jakarta: Rineka Cipta

Dokumen kurikulum SMP Negeri Mamba'ul Falah Kedungliwung Kemiri Singojuruh Kabupaten Banyuwangi.

Depag-RI. (2012). Al-Quran surat At-Taubah Ayat 122

Sugiyono. (2015). Metode Penelitian Pendidikan (Pendekatan Kuantitatif, Kualitatif dan $R \& D)$. Bandung,Penerbit. Alfabeta

Undang-undang No. 20 Tahun 2003 tentang Sistem Pendidikan Nasional 